\title{
Problem nadzoru właścicielskiego we współczesnym przedsiębiorstwie
}

\author{
Bogustaw Kaczmarek ${ }^{\star}$
}

Streszczenie: W opracowaniu prezentowane są następujące zagadnienia: 1) tradycyjne (statutowe) ujęcie funkcji rady nadzorczej w spółce akcyjnej oraz 2) zmodyfikowane niekodeksowe koncepcje funkcji rady nadzorczej we współczesnych przedsiębiorstwach z wykorzystaniem teorii agencji, teorii stewarda oraz koncepcji E. Gutenberga.

Słowa kluczowe: przedsiębiorstwo, nadzór właścicielski, nadzór korporacyjny, rada nadzorcza, zarządzanie

\section{Wstęp}

Niezależnie od przyjętego w teorii i praktyce modelu sprawowania władzy w spółce - monistycznego czy dualistycznego, istota problemu nadzoru właścicielskiego polega i sprowadza się do tego, w jaki sposób dokonać podziału zadań, kompetencji (usprawnień) i odpowiedzialności pomiędzy organami władzy lub osobami odpowiedzialnymi za bieżące zarządzanie, formułowanie strategii, misji i wizji przedsiębiorstwa oraz za nadzór nad jego działalnością w całości albo jego wyodrębnionych segmentów lub jednostek.

Według obowiązującego obecnie w Polsce Kodeksu Spółek Handlowych (k.s.h.) system władzy w spółkach akcyjnych współtworzą trzy następujące organy:

- walne zagrodzenie akcjonariuszy (wspólników);

- rada nadzorcza;

- zarząd spółki (przedsiębiorstwa).

Organy władzy w spółkach akcyjnych zaprezentowane są na rysunku 1.

* Uniwersytet Łódzki, Wydział Zarządzania. 


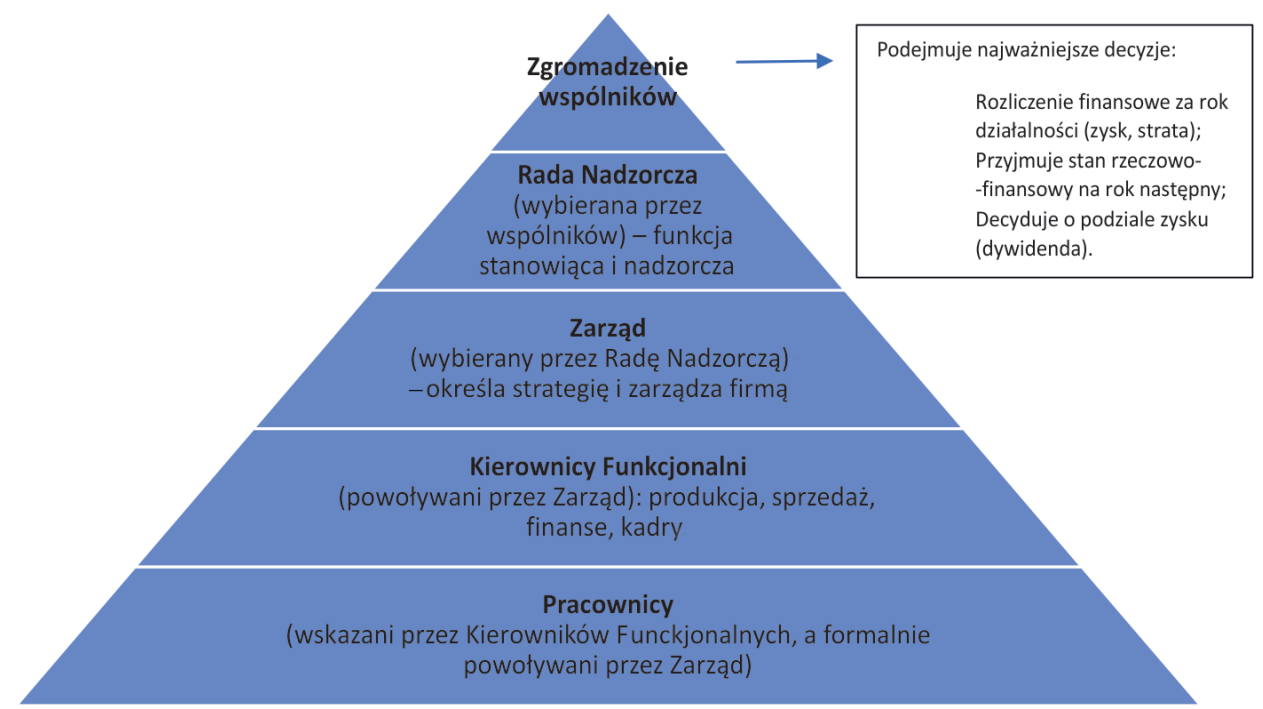

Rysunek 1. Organy władzy w spółkach akcyjnych Źródto: opracowanie własne.

Organami władzy spółki są także kierownicy funkcjonalni powoływani i odwoływani przez zarząd, o czym Kodeks spółek handlowych nie wspomina. Szczególną rolę w organach władzy spółek handlowych (przedsiębiorstw) pełni rada nadzorcza. Jest ona organem kontroli właścicielskiej poprzez to, że dokonuje „oceny działań podejmowanych przez członków Zarządu, oceny ich kompetencji menedżerskich oraz ich wkładu w realizację oczekiwań akcjonariuszy danej spółki”'.

Celem niniejszego opracowania jest przedstawienie ważniejszych - zdaniem autora - nurtów (koncepcji) ogólnoświatowej dyskusji na temat roli rad nadzorczych w procesie nadzoru właścicielskiego oraz w procesie poprawy efektywności działania spółek.

\section{W czyim interesie działają członkowie rady nadzorczej?}

Podstawowe pytanie brzmi: w czyim interesie powinna działać rada nadzorcza: $\mathrm{w}$ interesie poszczególnych akcjonariuszy, czy w interesie spółki?

Wybitni eksperci z zakresu prawa spółek wskazują, że „członkowie rad nadzorczych spółek powinni kierować się zasadą równego traktowania wszystkich

1 P. Urbanek, Nadzór korporacyjny a wynagrodzenia menedżerów, Wydawnictwo UŁ, Łódź 2005, s. 301. 
akcjonariuszy, co oznacza, że w swoich decyzjach winni kierować się przede wszystkim interesem spółki, czyli wszystkich akcjonariuszy. Interes spółki zatem nie może być utożsamiany z interesem części, a nawet większości akcjonariuszy”2 ${ }^{2}$. Wymieniona wyżej zasada równego traktowania wszystkich akcjonariuszy praktycznie nabiera szczególnego znaczenia, bo nie dzieli ich na tzw. większościowych i mniejszościowych. To prowadzi do „osiągnięcia racjonalnego kompromisu na forum rady nadzorczej i zapobiega niedopuszczalnym uprzywilejowaniom niektórych akcjonariuszy"3. Tyle stan formalno-prawny rozumienia, w czyim interesie działają członkowie rady nadzorczej w przedsiębiorstwie (spółce). Czy to jednak wystarcza do harmonii na linii: rada nadzorcza, akcjonariusze, interes spółki? J. Jeżak stwierdza, że „praktyka funkcjonowania polskich spółek nie potwierdza niestety tej harmonii”"

Brak jednak kompleksowych badań w tym zakresie tematycznym, na postawie których można byłoby ocenić skalę tego zjawiska, a co ważniejsze, bardzo trudno znaleźć w literaturze przedmiotu pomysły, jak temu zaradzić. Można wskazać, że wyjściem jest formułowanie tzw. kodeksu dobrych praktyk w zakresie nadzoru korporacyjnego, ale jest to zalecenie nieformalne.

\section{Tradycyjne (kodeksowe) ujęcie funkcji rady nadzorczej w spółce akcyjnej}

Podstawowym zadaniem rady nadzorczej jest stały nadzór nad działalnością spółki we wszystkich jej dziedzinach działalności. Rada nadzorcza nie ma przy tym prawa do wydawania zarządowi jakichkolwiek poleceń dotyczących spraw spółki. Do jej szczególnych obowiązków należy natomiast ocena sprawozdań zarządu z działalności spółki oraz sprawozdań finansowych w zakresie ich zgodności z księgami i dokumentami oraz ze stanem faktycznym. Kolejnym zadaniem spółki jest ocena wniosków zarządu dotycząca podziału zysku albo pokrycia straty, a także składanie walnemu zgromadzeniu akcjonariuszy corocznego pisemnego sprawozdania z wyników tych ocen ${ }^{5}$.

Kodeks spółek handlowych wymienia dwie podstawowe funkcje rady nadzorczej:

- funkcję nadzorczą;

- funkcję stanowiącą.

2 S. Sołtysiński, A. Szajkowski, A. Szymański, J. Szwaja, Kodeks spółek handlowych, t. III, Wydawnictwo C.H. Beck, Warszawa 2008, s. 1953.

3 Ibidem, s. 1457.

4 J. Jeżak, Rada Nadzorcza a sytuacja kryzysowa w spótce, [w:] P. Urbanek (red.), Nadzór korporacyjny w warunkach kryzysu gospodarczego, Wydawnictwo Ut, Łódź 2010, s. 54.

5 Art. $382 \S 1,2,3$ k.s.h. 
Funkcja nadzorcza to stały nadzór nad działalnością spółki we wszystkich dziedzinach jej funkcjonowania. Funkcja nadzorcza oznacza konieczność bieżącego śledzenia wszystkich zjawisk zachodzących w przedsiębiorstwie: rynkowych, ekonomiczno-finansowych, technicznych oraz społecznych. Jeśli dodamy do tego często spotykaną w praktyce różnorodność działalności prowadzonej przez współczesne przedsiębiorstwa (działalność rynkowa, handlowa, usługowa) oraz ich rosnące powiazania z gospodarką europejską/światową, to otrzymamy obraz szerokiego spektrum analiz i działań, jakie powinna prowadzić rada nadzorcza, aby mogła dobrze spełniać swoją funkcję stałego nadzoru.

Funkcja stanowiąca to powoływanie, odwoływanie oraz zawieszanie w czynnościach członków zarządu - poszczególnych lub wszystkich - oraz delegowanie członków rady nadzorczej do czasowego wykonywania czynności członków zarządu niemogących sprawować swoich czynności ${ }^{6}$. Ponadto status spółki może rozszerzyć uprawnienia rady nadzorczej w zakresie funkcji stanowiącej, przyjmując, że zarząd jest zobowiązany uzyskać zgodę rady nadzorczej przed dokonaniem określonych w statusie czynności. Równocześnie zawarto jednak zastrzeżenie, że jeżeli rada nadzorcza nie wyraża zgody na dokonanie określonych czynności, zarząd może zwrócić się do walnego zgromadzenia akcjonariuszy, aby złożyło uchwałę uchylającą zgodę na dokonanie tej czynności ${ }^{7}$.

Powoływanie, odwoływanie i zawieszanie w działalności poszczególnych członków lub całego zarządu spółki wiąże się bezpośrednio z systematyczną oceną przez radę nadzorczą jakości zarządzania spółką, osiągania celów i zadań strategicznych, sprawności działań zarządu spółki. Trzeba się zgodzić z tym, że ujęcie kodeksowe funkcji rady nadzorczej w spółce nie oddaje ogromu treści i zadań, jakie kryją się za sformułowaniem „stały nadzór nad działalnością spółki we wszystkich dziedzinach jej działalności”.

\section{Wspótczesne pomysły na funkcję rady nadzorczej w spółkach akcyjnych}

Powyższe stwierdzenie prowadzi do wniosku, że zakres usytuowania i uprawnień rady nadzorczej w procesie nadzoru właścicielskiego we współczesnych przedsiębiorstwach wymaga nieco rozszerzonego i bardziej kompleksowego spojrzenia.

Te współczesne pomysły prezentowane są w postaci bazy teoretycznej nadzoru właścicielskiego (korporacyjnego), obejmującej teorię agencji i teorię stewarda

6 Art. $382 \S 1$ k.s.h.

7 Art. $382 \S 1$ i 2 k.s.h. 
oraz w postaci szerszego rozumienia funkcji rady nadzorczej niż zakłada do $\mathrm{KSH}^{8}$. Interesujące jest to, że teoria agencji i teoria stewarda nie powstały na gruncie zarządzania, lecz na gruncie ekonomii instytucjonalnej'.

Generalnie w obu teoriach chodzi o zachowania menedżerów wchodzących w skład rad nadzorczych i o rolę rad nadzorczych w stosunku do zarządów przedsiębiorstwa. I tak, teoria agencji - dominująca w angielskim systemie nadzoru, zakłada z natury brak zaufania pomiędzy radą nadzorczą (zespołem kontrolującym) a zarządem przedsiębiorstwa (zespołem zarządzającym). Odwrotne założenie leży u podstaw teorii stewarda, bardziej honorowanej w europejskich systemach nadzoru korporacyjnego i w Japonii ${ }^{10}$. Zakłada ona, że członkowie zarządu w trosce o swoją pozycję na rynku pracy menedżerów będą należycie dbali o interesy spółki, przedkładając je nad bieżące-osobiste wpływy finansowe, bo to decyduje o perspektywie ich dalszych awansów i rozwoju zawodowego. Zestawienie najbardziej istotnych cech teorii agencji i teorii stewarda zawiera tabela 1.

Tabela 1. Porównanie istoty teorii agencji i teorii stewarda

\begin{tabular}{|c|c|}
\hline W teorii agencji: & W teorii stewarda: \\
\hline $\begin{array}{l}\text { 1. Akcentuje się sprawny mechanizm nadzoru } \\
\text { Rady wobec Zarządu (decyzje finansowe } \\
\text { podejmowane przez Zarząd, powyżej pew- } \\
\text { nej umownej sumy - podpisuje Rada). } \\
\text { 2. Rada stale kontroluje pracę Zarządu. } \\
\text { 3. Zwraca się istotną uwagę na maksymali- } \\
\text { zację własnej użyteczności menedżerów } \\
\text { Zarządu i akcjonariuszy, w imieniu których } \\
\text { oni działają, czyli agenta i pryncypała. } \\
\text { 4. Bazą teoretyczną filozofii teorii agencji jest } \\
\text { teza „X” McGregora. } \\
\text { 5. Rada nadzorcza reprezentuje właścicieli } \\
\text { i ma wobec nich zobowiązania. } \\
\text { 6. Motywacja do pracy jest wyłącznie finansowa. } \\
\text { 7. Posiadanie akcji przez menedżerów to kosz- } \\
\text { ty, które muszą przynieść dodatnie wyniki. } \\
\text { 8. W podejmowaniu decyzji menedżerowie } \\
\text { nie uwzględniają czynników sytuacyjnych, } \\
\text { obowiązuje racjonalizm ekonomiczny. }\end{array}$ & $\begin{array}{l}\text { 1. Rada nadzorcza ma uznanie i wiarygod- } \\
\text { ność ze strony Zarządu. } \\
\text { 2. Tworzenie relacji Rady nadzorczej odbywa } \\
\text { się na bazie zaufania. } \\
\text { 3. Bazą teoretyczną filozofii stewarda jest } \\
\text { teoria „Y” McGregora. } \\
\text { 4. Motywem podstawowym członków Za- } \\
\text { rządu jest czerpanie satysfakcji z dobrze } \\
\text { wykonanej pracy. } \\
\text { 5. Wysoko cenione są zachowania proorgani- } \\
\text { zacyjne. } \\
\text { 6. Nie ma konfliktów między Zarządem a ak- } \\
\text { cjonariuszami. } \\
\text { 7. Zagadnienia finansowe w motywacji pra- } \\
\text { cowniczej nie odgrywają zasadniczej roli. } \\
\text { 8. Nie ma powodów, tzn. Rada nie ma powo- } \\
\text { dów, do stosowania kosztownych sposo- } \\
\text { bów motywowania, wystarczy satysfakcjo- } \\
\text { nujace wynagrodzenie. }\end{array}$ \\
\hline
\end{tabular}

Źródło: opracowanie własne.

8 B. Glinkowska, B. Kaczmarek, Classical and modern concepst of corporate governance (Stewardship Theory and Agency Theory), „Management” (1429-9321), 2015, vol. 19, no 2, s. 84-92.

9 S. Rudolf, T. Janusz, D. Stos, P. Urbanek, Efektywny nadzór korporacyjny, PWE, Warszawa 2012, s. 36.

10 A. Peszko, Rada Nadzorcza w procesie zarządzania przedsiębiorstwem, Wydawnictwo Difin, Warszawa 2010, s. 97. 
Zachowania menedżerów zarządu w rozumowaniu teorii agencji determinują potrzeby ekonomiczne (wynagrodzenie), a podstawowym zadaniem rady jest tu kontrola zarządu. Natomiast zachowania menedżerów zarządu w rozumieniu teorii stewarda determinowane są przez potrzebę samorealizacji, a podstawowym zadaniem rady nadzorczej jest wspieranie zarządu w jego działalności.

Godzi się jednak zauważyć, że obie teorie (agencji i stewarda) oparte są na dwóch krańcowo różnych założeniach, lecz żadna z nich nie była poddana wystarczającemu testowaniu. Teoria agencji akcentuje to, że racjonalnie zachowująca się jednostka (menedżer - członek zarządu), działając we własnym interesie, dąży jedynie do maksymalizacji własnej użyteczności. Ale dorobek nauk o zarządzaniu wskazuje, że to może być jedna z postaw zachowań menedżerów, ale nie wszystkie. Teoria stewarda ${ }^{11}$ ma swoje korzenie w psychologii i socjologii organizacji, a szczególnie w teorii „Y” McGregora i akcentuje proorganizacyjne zachowania menedżerów czerpiących satysfakcję z dobrze wykonanej pracy, czyli inaczej mówiąc - podkreśla istotną rolę psychologicznych i sytuacyjnych determinant $\mathrm{w}$ nadzorze korporacyjnym, czego nie zauważa $\mathrm{w}$ ogóle teoria agencji. W tabeli 2. przedstawiono rolę i znaczenie psychologicznych i sytuacyjnych determinantów nadzoru korporacyjnego w rozumieniu teorii agencji i stewarda.

Tabela 2. Psychologiczne i sytuacyjne determinanty nadzoru korporacyjnego

\begin{tabular}{|l|l|l|}
\cline { 2 - 3 } \multicolumn{2}{c|}{} & \multicolumn{2}{c|}{ Teoria agencji } & \multicolumn{1}{c|}{ Teoria stewarda } \\
\hline \multicolumn{3}{|c|}{ Czynniki psychologiczne } \\
\hline Motywacja & $\begin{array}{l}\text { Potrzeby ekonomiczne (fi- } \\
\text { zjologiczne, bezpieczeństwa } \\
\text { ekonomicznego) } \\
\text { Zewnętrzna }\end{array}$ & $\begin{array}{l}\text { Potrzeby wyższego rzędu } \\
\text { (rozwój, osiągnięcia, samore- } \\
\text { alizacja) } \\
\text { Wewnętrzna }\end{array}$ \\
\hline Społeczne porównanie & Inni menedżerowie & Pryncypat \\
\hline Identyfikacja & Niska wartość zobowiązania & $\begin{array}{l}\text { Wysoka wartość zobowiąza- } \\
\text { nia }\end{array}$ \\
\hline Władza & $\begin{array}{l}\text { Instytucjonalna (usankcjo- } \\
\text { nowana prawnie, przymus, } \\
\text { nagrody i kary) }\end{array}$ & Osobowa (fachowiec) \\
\hline \multicolumn{2}{|c|}{ Czynniki sytuacyjne } & Orientacja na zaangażowanie \\
\hline Filozofia zarządzania & Orientacja na kontrolę & Zaufanie \\
\hline Podejście do ryzyka & Mechanizmy kontroli & $\begin{array}{l}\text { Kolektywizm } \\
\text { Niski dystans władzy }\end{array}$ \\
\hline Różnice kulturowe & $\begin{array}{l}\text { Indywidualizm } \\
\text { Duży dystans władzy }\end{array}$ &
\end{tabular}

Źródto: opracowanie własne.

11 Za twórcę teorii stewarda uznawany jest L. Donaldson. Zob. L. Donaldson, Organizational Economics and Management Theory, "Academy of Management Rewiev" 2009, vol. 15, no 3, N.Y. 
Wydaje się, że teoria stewarda nie powinna stanowić alternatywy dla teorii agencji, ale jej rozszerzenie wskazuje na różne możliwości jej praktycznego wykorzystania. I tak np. model finansowy przedsiębiorstwa jest w oczywisty sposób powiązany z teorią agencji, a model społeczny przedsiębiorstwa i to, co nazywamy społeczną odpowiedzialnością przedsiębiorstw, bliski jest teorii stewarda.

\section{Zmodyfikowany zarys koncepcji roli rady nadzorczej w procesie nadzoru właścicielskiego}

Wielu teoretyków i praktyków zarządzania uważa, że współczesny zakres rzeczywistej działalności rady nadzorczej powinien być znacznie szerszy niż ujmują to rozwiązania kodeksowe ${ }^{12}$. Potrzebne jest zatem bardziej kompleksowe spojrzenie na funkcje rady odpowiadające charakterowi współczesnego zarządzania oraz uwarunkowaniom, w jakich działa współczesne przedsiębiorstwo. Przypomnijmy, że w tradycyjnym (kodeksowym) ujęciu rada nadzorcza pełni dwie podstawowe funkcje - nadzorczą i stanowiącą.

Współcześnie lansowane jest ujęcie zmodyfikowane wskazujące, że aby rada nadzorcza mogła skutecznie funkcjonować - szczególnie dotyczy to diagnozowania sytuacji przedsiębiorstwa, przezwyciężania sytuacji kryzysowych i projektowania działalności przedsiębiorstwa - konieczne jest poszerzenie uprawnień i kompetencji, czyli zakresu pełnionych funkcji przez radę.

E. Gutenberg - jeden z twórców niemieckiej nauki o przedsiębiorstwie - wskazuje na następujące funkcje rady $^{13}$ :

1) funkcja nadzorcza,

2) funkcja kontrolna,

3) funkcja doradcza,

4) funkcja decyzyjna,

5) funkcja współpracy i wymiany informacji,

6) funkcja koordynacyjna.

To istotne rozszerzenie funkcji i roli rad nadzorczych w procesie nadzoru korporacyjnego zmierza w kierunku jak najpełniejszego wykorzystania kwalifikacji, doświadczenia i umiejętności członków rad, czyli inaczej mówiąc, ich potencjału intelektualnego. Szczególnie mocno akcentowane są także nowe zadania rad nadzorczych, jak coroczne przegotowanie własnej oceny sytuacji ekonomiczno-finansowej, rynkowej i organizacyjnej spółki; wskazywanie na potencjalne zagrożenia

12 Patrz: S. Douma, The two-tier System of Corporate Governance, "Long Range Planning" 2007, no 4, s. 613.

13 E. Gutenberg, Funktionswandel des Aufsichtsrats, „Zeitschrift für Betriebswirtschaft“ 2000, 12, s. 18. 
dla dotychczasowej pozycji spółki na rynku krajowym, międzynarodowym i globalnym; aktywne uczestniczenie w formułowaniu strategii spółki itp.

Rada nadzorcza jako reprezentant wszystkich akcjonariuszy spółki, czyli dostarczycieli kapitału finansowego do spółki, powinna w pierwszym rzędzie analizować i oceniać wykorzystanie tego kapitału i przełożenie go (transformacja) na dodatnie wyniki ekonomiczno-finansowe spółki. Wiedza w połączeniu z doświadczeniem zawodowym członków rady powinna stać się częścią składową procesu decyzyjnego w spółce - „Rada, która tylko nadzoruje należy już do przeszłości” ${ }^{14}$.

Jednocześnie - $\mathrm{i}$ jest to absolutnie jednoznacznie pojmowane - rada nadzorcza powinna przedstawiać zgromadzeniu wspólników analizę tzw. wskaźników niefinansowych, tj.: cykl życia produktów, czyli inaczej stopień ich odnawiania; zarządzanie talentami w spółce; rozwój systemów informatycznych i teleinformatycznych w firmie; rozwój systemów motywacyjnych i ich związków z jakością pracy; tzw. marketing relacji - czyli poziom współpracy z dostawcami, odbiorcami, kooperantami, kluczowymi interesariuszami firmy itp. J. Jeżak twierdzi, że „dopiero połączenie wskaźników finansowych i niefinansowych może być podstawą do oceny zdrowia spółki przez radę nadzorczą"15.

Warunkiem sine qua non należytego realizowania przez radę w/w rozszerzonych funkcji w procesie nadzoru właścicielskiego jest odpowiednia jakość informacji oraz sprawny system ich przebiegu w relacji zarząd - rada nadzorcza, dotyczący „polityki informacyjnej” w spółce, zarówno wewnętrznej, jak i zewnętrznej. „Spółka powinna zapewnić efektywny dostęp do informacji niezbędnych do oceny sytuacji i perspektywy spółki, sposobu jej funkcjonowania oraz przyjętych rozwiązań w zakresie nadzoru korporacyjnego"16.

\section{Zakończenie}

Wydaje się, że słabości funkcjonowania rad nadzorczych w klasycznej (ale statutowej) ich roli i funkcji w procesie nadzoru korporacyjnego spowodowały powstanie tzw. zmodyfikowanych ujęć funkcjonowania rad, o których była mowa w niniejszym opracowaniu. Najważniejsze jednak jest to, że te nowe pomysły (niestatutowe) wymagają prowadzenia pogłębionych analiz procesu ewolucji systemu nadzoru korporacyjnego. $\mathrm{Z}$ tych analiz powinny wynikać konstruktywne wnioski do budowy i kształtowania przyszłej teorii i praktyki nadzoru we współczesnych przedsiębiorstwach.

14 J. Strassen, Dieses Know-How muss ein Verwaltungsrat mitbringen, „Management Zeitschrift“ 2009, 5, s. 28.

15 J. Jeżak, op. cit., s. 55.

16 Kodeks nadzoru korporacyjnego dla spółek publicznych, Polskie Forum Corporate Governance, Gdańsk 2004, s. 8. 


\title{
Bibliografia
}

Donaldson L., Organizational Economics and Management Theory, "Academy of Management Review" 2009, vol. 15, no 3, N.Y.

Douma S., The two-tier System of Corporate Governance, "Long Range Planning" 2007, no 4, s. 613.

Glinkowska B., Kaczmarek B., Classical and modern concepst of corporate governance (Stewardship Theory and Agency Theory), „Management” (1429-9321), 2015, vol. 19, no 2, s. 84-92.

Gutenberg E., Funktionswandel des Aufsichtsrats, „Zeitschrift für Betriebswirtschaft" 2000, 12, s. 18.

Jeżak J., Rada Nadzorcza a sytuacja kryzysowa w spółce, [w:] P. Urbanek (red.), Nadzór korporacyjny w warunkach kryzysu gospodarczego, Wydawnictwo UŁ, Łódź 2010.

Kodeks nadzoru korporacyjnego dla spółek publicznych, Polskie Forum Corporate Governance, Gdańsk 2004.

Peszko A., Rada Nadzorcza w procesie zarzadzania przedsiębiorstwem, Wydawnictwo Difin, Warszawa 2010.

Rudolf S., Janusz T., Stos D., Urbanek P., Efektywny nadzór korporacyjny, PWE, Warszawa 2012.

Sołtysiński S., Szajkowski A., Szymański A., Szwaja J., Kodeks spółek handlowych, t. 3, Wydawnictwo C.H. Beck, Warszawa 2008.

Strassen J., Dieses Know-How muss ein Verwaltungsrat mitbringen, „Management Zeitschrift“ 2009, 5, s. 28.

Urbanek P., Nadzór korporacyjny a wynagrodzenia menedżerów, Wydawnictwo UŁ, Łódź 2005.

Urbanek P., Nadzór korporacyjny w warunkach kryzysu gospodarczego, Wydawnictwo UŁ, Łódź 2010.

\section{The problem of owner supervision in contemporary enterprises}

\begin{abstract}
Summary the following issues are presented in the paper: 1) traditional (statutory) recognition of the supervisory board function in a joint-stock company, and 2) modified non-expressive concepts of the supervisory board functions in modern enterprises using agency theory, steward theory and E. Gutenberg's concept.
\end{abstract}

Keywords: enterprise, corporate governance, management, supervisory board. 